\title{
PENGARUH KOMPETENSI DAN KOMITMEN ORGANISASI TERHADAP KINERJA PEGAWAI
}

\author{
FERRY ANDRE AGUSTIAN* \\ DJOKO POERNOMO \\ ZARAH PUSPITANINGTYAS \\ Jurusan Ilmu Administrasi \\ Fakultas Ilmu Sosial dan Ilmu Politik \\ Universitas Jember \\ *Email: ferry.andre.fa@gmail.com
}

\begin{abstract}
ABSTRAK
Penelitian dengan judul Pengaruh Kompetensi dan Komitmen Organisasi terhadap Kinerja Pegawai bertujuan mengetahui dan menjelaskan pengaruh kompetensi dan komitmen organisasi terhadap kinerja pegawai. Penelitian ini menggunakan desain penelitian kausalitas dan merupakan tipe penelitian hubungan atau asosiatif dengan menggunakan data kuantitatif. Teknik pengumpulan data yang digunakan adalah kuesioner, observasi, dan wawancara. Populasi dalam penelitian ini adalah seluruh pegawai di Badan Pengelolaan Keuangan dan Aset Daerah Kabupaten Jember, sejumlah 57 orang. Teknik sampling dalam penelitian ini menggunakan sampel jenuh. Analisis data yang digunakan untuk menjawab hipotesis yang diajukan adalah regresi linier berganda dengan bantuan paket software SPSS 17.0. Hasil penelitian menunjukkan bahwa kompetensi berpengaruh terhadap kinerja pegawai. Komitmen organisasi berpengaruh terhadap kinerja pegawai.
\end{abstract}

Kata Kunci: Kompetensi, Komitmen Organisasi, Kinerja Pegawai 


\section{PENDAHULUAN}

Dalam rangka mewujudkan pemerintahan yang bersih dan berwibawa diperlukan adanya kinerja aparatur yang bersih, professional, kapabel dan akuntabel sehingga dapat memberikan kontribusi bagi terselenggaranya suatu good governance. Aparatur pemerintah harus dibuat lebih professional, untuk meningkatkan fungsi pelayanan publiknya. Dengan profesionalisme aparatur akan bisa percaya diri (self confident) karena kemampuan memecahkan masalah (problem solving) yang selalu memihak pada kepentingan rakyat.

Gambaran mengenai kinerja aparatur pemerintah di saat masih jauh dari cita-cita yang dicanangkan oleh reformasi birokrasi. Indonesia masih menghadapi hambatan dalam rendahnya kinerja pelayanan birokrasi dan masih tingginya angka korupsi. Hal ini tergambar dari beberapa laporan kinerja pemerintahan seperti The Global Competitiveness Report 2014-2015 (World Economic Forum, 2015) dimana Indonesia menempati peringkat 37 dari 140 negara, dan laporan Bank Dunia melalui Worlwide Governance Indicators yang menunjukkan bahwa efektivitas pemerintahan

(Government Effectiveness) Indonesia masih sangat rendah, dengan nilai indeks di tahun 2014 adalah - 0, 01. Selain itu Indeks Persepsi Korupsi (The Corruption Perceptions Index) Indonesia berdasarkan data dari Transparency International juga masih rendah pada nilai indeks 34 (dari nilai indeks bersih korupsi 100) dan berada pada ranking 107 dari 175 negara pada tahun 2014. Hal ini tentunya menjadi kendala karena pembangunan nasional dalam era persaingan global menuntut adanya birokrasi yang efisien, berkualitas, transparan, dan akuntabel, terutama terhadap prospek bidang investasi di Indonesia.

Keberhasilan suatu organisasi tidak luput dari peranan manajemen sumber daya manusia yang efektif dan efisien. Sumber Daya Manusia (SDM) dalam suatu organisasi merupakan faktor yang sangat menentukan dalam pencapaian tujuan organisasi baik pemerintahan 
maupun organisasi. Kinerja organisasi pemerintah di sektor publik menjadi topik berbagai kajian di bidang SDM baik yang diselenggarakan oleh institusi pemerintahan, praktisi, maupun akademisi. Kinerja dalam organisasi dianggap menjadi salah satu tolak ukur dalam pencapaian tujuan organisasi.

Organisasi perlu melakukan upaya pengembangan kompetensi secara sistematis. Hasil penelitian Mc. Clelland (dalam Supiyanto, 2015) menunjukkan bahwa kompetensi berhasil memprediksi kinerja atau prestasi kerja individu dalam pekerjaan. Temuan penelitian Isnain (2012) menyatakan bahwa kompetensi berpengaruh positif terhadap kinerja pegawai. Dari pola pikir tersebut selanjutnya Wibowo (2007) mengembangkan dimensi kompetensi yang terdiri dari; pengetahuan, kemampuan, sikap, gaya kerja, kepribadian, dasar-dasar nilai sikap, kepercayaan dan gaya kepemimpinan yang akan mempengaruhi kinerja karyawan.

Komitmen organisasi yang dirasakan pegawai dapat menimbulkan perilaku positif terhadap organisasi kerja dan memiliki andil terhadap kinerja pegawai. Hasil penelitian Harun (2016) menyatakan bahwa terdapat pengaruh positif komitmen organisasi terhadap kinerja pegawai. Temuan yang sama diperoleh dari penelitian Supiyanto, (2015) yang menyatakan bahwa komitmen organisasi berpengaruh positif signifikan terhadap kinerja karyawan, sehingga jika komitmen organisasi tinggi maka kinerja karyawan juga tinggi dan sebaliknya jika komitmen organisasi rendah maka kinerja karyawan juga rendah. Steers (dalam Handoko, 2008) menyebutkan bahwa komitmen yang kuat dapat membawa dampak positif, antara lain: peningkatan prestasi kerja, motivasi kerja, masa kerja, produktivitas kerja, dan karyawan lebih rajin masuk kerja sehingga mengurangi absensi dan menurunkan turn over.

Berdasarkan kutipan-kutipan dari beberapa jurnal di atas, bisa dikatakan bahwa kompetensi dan komitmen organisasi merupakan faktor yang dapat mengarah pada 
pencapain kinerja pegawai.

Berdasarkan uraian di atas penelitian ini bertujuan untuk mengkaji

\section{TINJAUAN PUSTAKA}

\subsection{Kompetensi}

Ada dua istilah yang muncul dari dua aliran yang berbeda tentang konsep kesesuaian dalam pekerjaan. Istilah tersebut adalah "Competency" (kompetensi) yaitu deskripsi mengenai perilaku, dan “Competence" (kecakapan) yang merupakan deskripsi tugas atau hasil pekerjaan (Palan, 2007: 5). Walau perbedaan arti kedua istilah tersebut diterima secara umum, namun penggunaannya masih sering dipertukarkan, yang menyebabkan setiap orang memiliki pengertian yang berbeda-beda. Umumnya orang menggunakan istilah kompetensi dan sejenisnya menciptakan pengertian sendiri sesuai dengan kepentingannya.

Zamkee (1982) yang dikutip oleh Palan (2007:6) mengatakan bahwa "Kompetensi (competence), model kompetensi dan pelatihan berbasis kompetensi merupakan kata yang bisa diartikan beragam pengaruh kompetensi dan komitmen organisasi terhadap kinerja pegawai.

mengikuti pendefinisiannya. Perbedaan makna tersebut bukan berasal dari kebodohan atau ketamakan pasar, tapi dari beberapa prosedur mendasar dan perbedaan filosofis diantara ahli yang berlomba untuk mendefinisikan dan membentuk konsep tersebut dan menetapkan model bagi pihak yang akan menggunakan kompetensi dalam upaya sehari-hari.

Kompetensi terkait dengan segala yang diketahui manusia tentang dirinya maupun lingkungannya. Hal ini diperoleh manusia melalui panca indra melalui rangkaian-rangkaian pengalaman manusia itu sendiri. Suriasumantri (2003: 104) berpendapat bahwa kompetensi merupakan khasanah kekayaan mental yang secara langsung atau tidak langsung dapat memperkaya kehidupan manusia. Dengan kompetensi manusia dapat memecahkan berbagai macam permasalahan yang dihadapinya 
sehingga kompetensi itu memiliki arti yang sangat penting dalam kehidupan manusia.

\subsection{Komitmen Organisasi}

Robbins dan Judge (2007) mendefinisikan komitmen sebagai suatu keadaan dimana seorang individu memihak organisasi serta tujuan-tujuan dan keinginannya untuk mempertahankan keangotaannya dalam organisasi. Sedangkan Mathis dan Jackson (dalam Sopiah, 2008: 155) mendefinisikan komitmen organisasi sebagai derajat dimana karyawan percaya dan mau menerima tujuantujuan organisasi dan akan tetap tinggal atau tidak akan meninggalkan organisasinya).

Steers (dalam Handoko, 2008) mendefinisikan komitmen organisasi sebagai rasa identifikasi (kepercayaan terhadap nilai-nilai organisasi), keterlibatan (kesediaan untuk berusaha sebaik mungkin demi kepentingan organisasi) dan loyalitas (keinginan untuk tetap menjadi anggota organisasi yang bersangkutan) yang dinyatakan oleh seorang pegawai terhadap organisasinya. Steers berpendapat bahwa komitmen organisasi merupakan kondisi dimana pegawai sangat tertarik terhadap tujuan, nilainilai, dan sasaran organisasinya. Komitmen terhadap organisasi artinya lebih dari sekedar keanggotaan formal, karena meliputi sikap menyukai organisasi dan kesediaan untuk mengusahakan tingkat upaya yang tinggi bagi kepentingan organisasi demi pencapaian tujuan.

Keputusan

Menteri

Pendayagunaan Aparatur Negara Republik Indonesia No.25/KEP/M.PAN/2002

menyatakan pengertian komitmen adalah keteguhan hati, tekad yang mantap, dan janji untuk melakukan atau mewujudkan sesuatu yang diyakini. Komitmen organisasi mencerminkan sejauh mana seorang individu mengidentifikasi organisasi dan tujuannya (Kreitner dan Kinicki, 2008). Menurut Robbins (2008) dalam perilaku organisasi, komitmen organisasi merupakan komponen dari perilaku. Komitmen organisasi adalah suatu keadaan dimana seorang karyawan memihak pada 
suatu organisasi dan tujuantujuannya, serta berniat memelihara keanggotaannya itu. Keterlibatan seseorang yang tinggi dalam suatu pekerjaan berarti memihak pada pekerjaan tertentu seorang individu, sementara komitmen organisasi yang tinggi berarti memihak organisasi yang merekrut individu tersebut.

\subsection{Kinerja Pegawai}

Istilah kinerja sering digunakan untuk menyebut prestasi atau tingkat keberhasilan individu maupun kelompok individu. Kinerja bisa diketahui hanya jika individu atau kelompok invidu tersebut mempunyai kriteria keberhasilan yang telah ditetapkan. Kriteria keberhasilan ini berupa tujuan-tujuan atau target-target tertentu yang hendak dicapai. Menurut Rivai (2005), kata kinerja merupakan terjemahan dari kata performance yang berasal dari kata to perform dengan beberapa entries, yaitu: (1) melakukan, menjalankan, melaksanakan (to do or carry out, execute); (2) memenuhi atau melaksanakan kewajiban suatu unit atau nazar (to discharge of fulfil; as vow); (3) melaksanakan atau menyempurnakan tanggungjawab (to execute or complete an understanding) dan (4) melakukan sesuatu yang diharapkan oleh orang atau mesin (to do what is expected of a person machine). Hersey and Blancard (1993) dalam Robbins (2008), kinerja merupakan suatu fungsi dari motivasi dan kemampuan. Untuk menyelesaikan tugas atau pekerjaan, seseorang harus memiliki derajat kesediaan dan tingkat kemampuan tertentu. Kesediaan dan keterampilan seseorang tidaklah cukup efektif untuk mengerjakan sesuatu tanpa pemahaman yang jelas tentang apa yang dikerjakan dan bagaimana mengerjakannya.

$$
\text { Mangkunegara }
$$
menyatakan bahwa kinerja Sumber Daya Manusia adalah istilah yang berasal dari kata Job Performance atau Actual Performance (Prestasi Kerja) yang berarti hasil kerja baik secara kualitas maupun secara kuantitas yang dicapai oleh seseorang karyawan/pegawai dalam melaksanakan tugasnya sesuai dengan tanggungjawab yang 
diberikan kepadanya. Selanjutnya, Sedarmayanti (2007) menyatakan bahwa kinerja adalah penggunaan sistem dalam menilai dan mengetahui apakah seorang karyawan telah melaksanakan pekerjaannya secara menyeluruh atau merupakan perpaduan hasil kerja (apa yang harus dicapai seseorang) dan kompetensi (bagaimana seseorang mencapainya).

\subsection{Hubungan Kompetensi dengan Kinerja Pegawai}

Kinerja dan keefektifan pegawai dalam melaksanakan tugas sangat ditentukan oleh kompetensi yang disyaratkan pada bidang pekerjaan tersebut. Kompetensi berpengaruh terhadap kinerja pegawai. Seorang pegawai yang memiliki kompetensi yang tinggi seperti pengetahuan, ketrampilan, kemampuan, dan sikap yang sesuai dengan jabatan yang diembannya selalu terdorong untuk bekerja secara efektif, efisien dan produktif. Hal ini terjadi karena dengan kompetensi yang dimiliki pegawai bersangkutan semakin mampu untuk melaksanakan tugastugas yang dibebankan kepadanya.
Kompetensi dapat berupa tujuan, perangai, konsep diri, sikap atau nilai, penguasaan masalah, atau ketrampilan kognitif maupun ketrampilan perilaku. Setiap sifat perorangan yang dapat diukur atau dihitung dengan jelas dan dapat ditunjukkan untuk membedakan secara jelas seorang perilaku unggul dari seorang perilaku efektif dari seorang pelaku yang tidak efektif. Dengan adanya kompentensi yang terampil akan menghasilkan kinerja yang baik pada pegawai. Terkait hal ini terdapat hubungan yang positif antar kompetensi dan kinerja pegawai dalam melakukan suatu pekerjaan.

$\mathrm{Ha}_{1}$ : Kompetensi berpengaruh terhadap kinerja pegawai.

\subsection{Hubungan Komitmen \\ Organisasi dengan Kinerja Pegawai}

Komitmen organisasi diperlukan sebagai salah satu hal yang mempengaruhi kinerja pegawai. Komitmen organisasi pada pegawai yang tinggi biasanya akan meningkatkan kinerja yang tinggi dan sekaligus dapat menurunkan 
tingkat absensi dan sebaliknya jika seorang pegawai memiliki tingkat komitmen rendah maka kinerjanya juga rendah (Nyhan, 2009).

Menurut Meyer dan Allen (1991 dalam Luthans, 2006) pada dasarnya pegawai itu ingin berkontribusi untuk mencapai tujuan organisasi dimana untuk mencapai tujuan organisasi ini telah dipengaruhi oleh sifat komitmen yang berbeda-beda sehingga tuntutan tersebut di atas menjadi semakin mendesak pada saat fleksibilitas fiskal mulai menurun seperti sekarang ini, sementara manajer pada lingkungan pemerintah memiliki kemampuan yang sangat terbatas untuk memberikan

\section{METODE PENELITIAN}

Metode penelitian ini yang digunakan dalam penelitian ini adalah menggunakan penelitian survei. Penelitian ini menggunakan desain penelitian kausalitas. Dalam penelitian ini variabel tidak bebasnya adalah kinerja pegawai (Y) dan variabel bebasnya adalah kompetensi $\left(\mathrm{X}_{1}\right)$ dan komitmen organisasi $\left(\mathrm{X}_{2}\right)$. Sumber data primer yang penulis penghargaan ekstrinsik seperti promosi dan kenaikan gaji/pangkat.

Penelitian Nasomboon (2014) dalam "The Relationship among Leadership

Commitmen

Organizational Performance and Employee Engagement" dijelaskan bahwa pemimpin yang berkomitmen dengan organisasi, bekerja dan fokus menuju tujuan organisasi mempengaruhi nilai kinerja organisasi. Dengan demikian penelitian ini memperkuat penelitian yang menyatakan bahwa komitmen organisasi mempengaruhi kinerja pegawai.

$\mathrm{Ha}_{2}$ : Komitmen organisasi berpengaruh terhadap kinerja pegawai.

ambil berasal dari wawancara, observasi, dan kuesioner. Sumber data sekunder diperoleh dari dokumentasi yang telah tersedia dan studi pustaka sebagai pelengkap data.

Mengenai analisis data yang digunakan oleh penulis adalah analisis kuantitatif, yaitu meyakinkan kebenaran dengan menggunakan metode statistik. Untuk menganalisis 
data yang diperoleh dan untuk kompetensi dan komitmen organisasi menguji hipotesis yang telah terhadap kinerja pegawai.

dirumuskan, maka penulis

$$
\mathrm{Y}=\alpha+\beta_{1} \mathrm{X}_{1}+\beta_{2} \mathrm{X}_{2}+\mathrm{e}
$$

menggunakan analisis regresi linier

berganda (multiple linear regression

analysis). Analisis ini digunakan

untuk mengetahui pengaruh

$$
\begin{array}{ll}
\text { Keterangan: } \\
\mathrm{Y} \quad=\text { Kinerja Pegawai } \\
\alpha & =\text { Konstanta } \\
\beta_{1-2} & =\text { Koefisien Regresi } \\
\mathrm{X}_{1} & =\text { Kompetensi } \\
\mathrm{X}_{2} & =\text { Komitmen Organisasi } \\
\mathrm{e} & =\text { Error }
\end{array}
$$

\section{HASIL PENELITIAN DAN PEMBAHASAN}

\subsection{Hasil Penelitian}

Berdasarkan Tabel 1, diperoleh persamaan regresi sebagai berikut:

$$
\mathrm{Y}=9,790+0,590 \mathrm{X}_{1}+0,366 \mathrm{X}_{2}
$$

Adapun interpretasi dari persamaan tersebut adalah:

1. Konstanta sebesar 9,790, menunjukkan besanya kinerja pegawai (Y) pada saat variabel kompetensi dan komitmen organisasi sama dengan nol, hal ini menunjukkan bahwa kinerja pegawai masih tercapai dan bernilai positif yang disebabkan olef faktor lain di luar model yang diteliti.
2. $\mathrm{b}_{1}=0,590$, artinya apabila variabel kepuasan pasien $\left(\mathrm{X}_{2}\right)$ sama dengan nol, maka semakin baiknya kompetensi $\left(\mathrm{X}_{1}\right)$ akan menyebabkan semakin baiknya kinerja pegawai (Y).

3. $\mathrm{b} 2=0,366$, artinya apabila variabel komitmen organisasi $\left(\mathrm{X}_{1}\right)$ sama dengan nol, maka semakin baiknya kepuasan pasien $\left(\mathrm{X}_{2}\right)$ akan menyebabkan semakin baiknya kinerja pegawai (Y). 
Tabel 1. Hasil Analisis Regresi Linier Berganda

\begin{tabular}{lcccl}
\hline \multicolumn{1}{c}{ Variabel } & $\begin{array}{c}\text { Koef. } \\
\text { Regresi }\end{array}$ & $\mathbf{t}_{\text {hitung }}$ & Sig. & Keterangan \\
\hline Konstanta & 9,790 & 1,254 & 0,215 & - \\
Kompetensi & 0,590 & 6,313 & 0,000 & Signifikan \\
Komitmen Org. & 0,366 & 3,173 & 0,002 & Signifikan \\
\hline & R Square & & 0,520 \\
& $\mathrm{~F}_{\text {hitung }}$ & & 29,213 \\
& $\mathrm{~F}_{\text {sig }}$ & & 0,000 \\
& $\mathrm{~N}$ & & 57 \\
\hline
\end{tabular}

Berdasarkan hasil analisis yang bisa dilihat pada Tabel 1 diperoleh hasil koefisien determinasi $\left(\mathrm{R}^{2}\right)$ sebesar 0,520 , hal ini berarti $52,0 \%$ variasi perubahan kinerja pegawai dapat dijelaskan oleh variabel kompetensi dan komitmen organisasi sedangkan sisanya sebesar $48,0 \%$ disebabkan oleh faktor lain yang tidak termasuk dalam persamaan regresi yang dibuat seperti gaya kepemimpinan, lingkungan kerja, budaya organisasi, dan lainnya.

Nilai F hitung sebesar 29,213 lebih besar daripada $\mathrm{F}$ tabel $(29,213$ $>3,232)$ dan nilai probabilitas $(\mathrm{P}$ value $)<0,05$ atau $(0,000<0,05)$ maka disimpulkan kompetensi dan komitmen organisasi terbukti berpengaruh secara bersama-sama dan signifikan terhadap kinerja pegawai.
Besarnya pengaruh masingmasing variabel bebas terhadap variabel terikat sebagai berikut:

1. Pengaruh variabel kompetensi $\left(\mathrm{X}_{1}\right)$ terhadap kinerja pegawai (Y)

Hasil pengujian untuk pengaruh variabel kompetensi $\left(\mathrm{X}_{1}\right)$ terhadap kinerja pegawai (Y) diperoleh $\mathrm{t}$ hitung sebesar 6,313 dan lebih besar dari t tabel $(6,313>2,009)$ dan nilai signifikansi $<\alpha(0,000<0,05)$. Karena tingkat probabilitasnya lebih kecil dari 5\%, maka $\mathrm{H}_{0}$ ditolak, berarti secara parsial variabel kompetensi mempunyai pengaruh signifikan terhadap kinerja pegawai.

2. Pengaruh variabel komitmen organisasi $\left(\mathrm{X}_{2}\right)$ terhadap kinerja pegawai (Y) 
Hasil pengujian untuk pengaruh variabel komitmen organisasi $\left(\mathrm{X}_{2}\right)$ terhadap kinerja pegawai (Y) t hitung sebesar 3,173 atau lebih besar dari t tabel $(3,173>2,009)$ dan signifikansi $<\alpha(0,001<0,05)$. Karena tingkat probabilitasnya lebih kecil dari 5\%, maka $\mathrm{H}_{0}$ ditolak, berarti secara parsial variabel komitmen organisasi mempunyai pengaruh signifikan terhadap kinerja pegawai.

\subsection{Pembahasan}

\section{Pengaruh Kompetensi terhadap Kinerja Pegawai}

Hasil uji regresi menunjukkan variabel kompetensi berpengaruh positif dan signifikan terhadap kinerja pegawai. Sehingga, hipotesis yang menyatakan kompetensi berpengaruh terhadap kinerja pegawai pada Badan Pengelolaan Keuangan dan Aset Daerah Kabupaten Jember terbukti kebenarannya ( $\mathrm{Ha}_{1}$ diterima).

Boyatzis (dalam Sudarmanto 2009:46) mengatakan kompetensi adalah karakteristik-karakteristik yang berhubungan dengan kinerja unggul dan atau efektif di dalam pekerjaan. Dan menurut Armstrong
(Sudarmanto, 2009:46) mengatakan kompetensi adalah apa yang orang bawa pada suatu pekerjaan dalam bentuk tipe dan tingkat-tingkat perilaku yang berbeda-beda. Kompetensi menentukan aspekaspek proses kinerja pekerjaan.

Kompetensi merupakan karakterisitik individu yang mendasari kinerja atau perilaku di tempat kerja. Dari pola pikir tersebut selanjutnya Wibowo (2007: 227) mengembangkan dimensi kompetensi yang terdiri dari; pengetahuan, kemampuan, sikap, gaya kerja, kepribadian, dasar-dasar nilai sikap, kepercayaan dan gaya kepemimpinan yang akan mempengaruhi kinerja karyawan. Standar kompetensi adalah ukuran atas kemampuan seseorang yang terobservasi yang mencakup atas pengetahuan, ketrampilan, dan sikap dalam menyelesaikan suatu pekerjaan atau tugas sesuai dengan standar performa yang ditetapkan. Standar kompetensi merupakan kesepakatan tentang kompetensi yang diperlukan untuk suatu bidang pekerjaan, dengan dikuasainya standar kompetensi tersebut oleh 
seseorang maka yang bersangkutan akan mampu; (1) mengerjakan suatu tugas atau pekerjaan, (2) mengelola pekerjaan tersebut agar dapat dilaksanakan, (3) mengetahui apa yang harus dilakukan jika terjadi sesuatu yang berbeda dengan rencana semula dan (4) menggunakan kemampuan yang dimilikinya untuk memecahkan masalah atau melaksanakan tugas dengan kondisi yang berbeda.

Kinerja seseorang dapat ditingkatkan apabila ada kesesuaian antara pekerjaan dan kemampuan (Robbins, 2008:83). Kemampuan individu adalah suatu faktor yang merujuk ke suatu kapasitas individu untuk mengerjakan berbagai tugas dalam suatu pekerjaan. Kompetensi menurut Spencer \& Spencer (dalam Palan, 2007:6) adalah karakteristik dasar yang dimiliki oleh seorang individu yang berhubungan secara kausal dalam memenuhi kriteria yang diperlukan dalam menduduki suatu jabatan. Kompetensi kerja merupakan suatu alat yang dapat digunakan untuk mengenali kemampuan, keterampilan, pengetahuan, motivasi, dan karakteristik pribadi yang sangat penting lainnya diperlukan untuk mencapai kinerja superior. Hal tersebut sesuai dengan pendapat Spencer-Spencer (dalam Palan, 2007:6) bahwa antara kompetensi dengan kinerja mempunyai hubungan sebab akibat (causally related) yang sangat erat sekali. Oleh karena itu apabila pegawai ingin meningkatkan kinerjanya, seharusnya mempunyai kompetensi kerja yang sesuai dengan tugas pekerjaannya.

Kinerja dan keefektifan pegawai dalam melaksanakan tugas sangat ditentukan oleh kompetensi yang disyaratkan pada bidang pekerjaan tersebut. Kompetensi berpengaruh terhadap kinerja pegawai. Seorang pegawai yang memiliki kompetensi yang tinggi seperti pengetahuan, ketrampilan, kemampuan, dan sikap yang sesuai dengan jabatan yang diembannya selalu terdorong untuk bekerja secara efektif, efisien dan produktif. Hal ini terjadi karena dengan kompetensi yang dimiliki pegawai bersangkutan semakin mampu untuk 
melaksanakan tugas-tugas yang dibebankan kepadanya.

Kompetensi dapat berupa tujuan, perangai, konsep diri, sikap atau nilai, penguasaan masalah, atau ketrampilan kognitif maupun ketrampilan perilaku. Setiap sifat perorangan yang dapat diukur atau dihitung dengan jelas dan dapat ditunjukkan untuk membedakan secara jelas seorang perilaku unggul dari seorang perilaku efektif dari seorang pelaku yang tidak efektif. Dengan adanya kompentensi yang terampil akan menghasilkan kinerja yang baik pada pegawai. Terkait hal ini terdapat hubungan yang positif antar kompetensi dan kinerja pegawai dalam melakukan suatu pekerjaan.

\section{Pengaruh}

Komitmen

\section{Organisasi terhadap Kinerja}

\section{Pegawai}

Hasil uji regresi menunjukkan variabel komitmen organisasi berpengaruh positif dan signifikan terhadap kinerja pegawai. Sehingga, hipotesis yang menyatakan komitmen organisasi berpengaruh terhadap kinerja pegawai terbukti kebenarannya ( $\mathrm{Ha}_{2}$ diterima).

Komitmen orgainsasi merupakan usaha untuk mengidentifikasikan diri dan melibatkan diri dalam organisasi dan berharap tetap menjadi anggota organisasi (Robbins, 2008). Komitmen organisasi diperlukan sebagai salah satu hal yang mempengaruhi kinerja pegawai. Komitmen organisasi pada pegawai yang tinggi biasanya akan meningkatkan kinerja yang tinggi dan sekaligus dapat menurunkan tingkat absensi dan sebaliknya jika seorang pegawai memiliki tingkat komitmen rendah maka kinerjanya juga rendah (Nyhan, 2009).

Menurut Meyer dan Allen (1991 dalam Luthans, 2006) pada dasarnya pegawai itu ingin berkontribusi untuk mencapai tujuan organisasi dimana untuk mencapai tujuan organisasi ini telah dipengaruhi oleh sifat komitmen yang berbeda-beda sehingga tuntutan tersebut di atas menjadi semakin mendesak pada saat fleksibilitas fiskal mulai menurun seperti sekarang ini, sementara manajer pada lingkungan pemerintah 
memiliki kemampuan yang sangat terbatas untuk memberikan penghargaan ekstrinsik seperti promosi dan kenaikan gaji/pangkat.

Komitmen organisasi dapat dibedakan menjadi tiga hal (Cheng dan Kalleberg, 1996 dalam Sopiah, 2008) yaitu:

1) Kemauan untuk melakukan usaha yang bermanfaat bagi kepentingan organisasi.

Keinginan yang kuat untuk mempertahankan keanggotaan dalam organisasi.

Kepercayaan dan penerimaan yang kuat terhadap tujuan dan nilai.

Steers (1988 dalam Handoko, 2008) mendefinisikan komitmen organisasi sebagai rasa identifikasi (kepercayaan terhadap nilai-nilai organisasi), keterlibatan (kesediaan untuk berusaha sebaik mungkin demi kepentingan organisasi) dan loyalitas (keinginan untuk tetap menjadi anggota organisasi yang bersangkutan) yang dinyatakan oleh seorang pegawai terhadap organisasinya. Steers berpendapat bahwa komitmen organisasi merupakan kondisi dimana pegawai sangat tertarik terhadap tujuan, nilai- nilai, dan sasaran organisasinya. Komitmen terhadap organisasi artinya lebih dari sekedar keanggotaan formal, karena meliputi sikap menyukai organisasi dan kesediaan untuk mengusahakan tingkat upaya yang tinggi bagi kepentingan organisasi demi pencapaian tujuan.

Komitmen organisasi diperlukan sebagai salah satu hal yang mempengaruhi kinerja pegawai. Komitmen organisasi pada pegawai yang tinggi biasanya akan meningkatkan kinerja yang tinggi dan sekaligus dapat menurunkan tingkat absensi dan sebaliknya jika seorang pegawai memiliki tingkat komitmen rendah maka kinerjanya juga rendah (Nyhan, 2009). Menurut Meyer dan Allen (1991 dalam Luthans, 2006) pada dasarnya pegawai itu ingin berkontribusi untuk mencapai tujuan organisasi dimana untuk mencapai tujuan organisasi ini telah dipengaruhi oleh sifat komitmen yang berbeda-beda sehingga tuntutan tersebut di atas menjadi semakin mendesak pada saat fleksibilitas fiskal mulai menurun seperti sekarang ini, sementara 
manajer pada lingkungan pemerintah memiliki kemampuan yang sangat terbatas untuk memberikan penghargaan ekstrinsik seperti promosi dan kenaikan gaji/pangkat.

Komitmen organisasi merupakan sifat hubungan antara individu dengan organisasi kerja, dimana individu mempunyai keyakinan diri terhadap nilai-nilai dan tujuan organisasi kerja, adanya kerelaan untuk menggunakan usahanya secara sungguh-sungguh demi kepentingan organisasi kerja serta mempunyai keinginan yang kuat untuk tetap menjadi bagian dari organisasi kerja. Seorang karyawan yang semula kurang memiliki komitmen berorganisasi, namun setelah bekerja ternyata selain mendapat imbalan sesuai dengan ketentuan yang berlaku ada hal-hal yang menarik dan memberi

\section{KESIMPULAN DAN SARAN}

\subsection{Kesimpulan}

Berdasarkan hasil analisis, maka dapat diambil beberapa kesimpulan sebagai berikut:

1. Kompetensi berpengaruh terhadap kinerja pegawai pada kepuasan. Hal itu akan memupuk berkembangnya komitmen berorganisasi. Apalagi jika banyak hal yang dapat memberikan kesejahteraan dan jaminan keamanan yang mendukung kegiatan kerja sehingga dapat bekerja dengan penuh semangat, lebih produktif dan efisien dalam menjalankan tugasnya.

Penelitian Nasomboon (2014) dalam "The Relationship among Leadership

Commitmen Organizational Performance and Employee Engagement" dijelaskan bahwa pemimpin yang berkomitmen dengan organisasi, bekerja dan fokus menuju tujuan organisasi mempengaruhi nilai kinerja organisasi. Dengan demikian penelitian ini memperkuat penelitian yang menyatakan bahwa komitmen organisasi mempengaruhi kinerja pegawai.

2. Komitmen organisasi berpengaruh terhadap kinerja pegawai pada Badan 
Pengelolaan Keuangan dan Aset

Daerah Kabupaten Jember.

\subsection{Saran}

Dari hasil penelitian ini kiranya peneliti dapat memberikan saran, diantaranya:

1. Hasil penelitian membuktikan bahwa kompetensi dan komitmen organisasi mempunyai pengaruh yang positif dan signifikan terhadap kinerja pegawai, oleh karena itu hendaknya instansi selalu memperhatikan hal-hal khususnya yang berkaitan dengan kompetensi dan komitmen organisasi. Berkaitan dengan kompetensi, aspek yang dinilai sudah baik sehingga perlu dipertahankan diantaranya penyelesaikan pekerjaan tanpa menunggu bantuan orang lain, pemahaman pegawai atas Standart Operational Procedure (SOP) yang berlaku dalam bidang pekerjaan, dan kesesuaian beban pekerjaan dengan tingkat pendidikan. Sedangkan aspek yang dinilai lemah sehingga perlu diperbaiki diantaranya pengungkapan pendapat pada saat rapat untuk pelaksanaan kegiatan, mengarahkan rekan-rekan kerja untuk menyelesaikan pekerjaan, dan berani berterus terang kepada atasan jika melakukan kesalahan kerja. Berkaitan dengan komitmen organisasi, aspek yang dinilai sudah baik sehingga perlu dipertahankan diantaranya pegawai merasa bahagia menerapkan nilai-nilai yang ada di organisasi, pegawai berusaha untuk bersikap setia atau loyal pada organisasi, dan pegawai menggabungkan diri pada organisasi tempat bekerja karena keinginannya sendiri. Sedangkan aspek yang dinilai lemah sehingga perlu diperbaiki diantaranya pegawai ingin melibatkan diri dalam upaya pencapaian tujuan organisasi, pegawai berfikir tidak akan mudah menjadi terikat dengan organisasi lain seperti pegawai terikat dengan organisasi ini, dan pegawai merasa organisasi telah mampu memberikan segala kebutuhan hidupnya. 
2. Hasil penelitian ini menyatakan bahwa variabel kompetensi dan komitmen organisasi hanya mampu menjelaskan kinerja pegawai sebesar 52,0\%, sehingga perlu dilakukan penelitian lanjutan dengan

\section{DAFTAR PUSTAKA}

Handoko, T. Hani, 2008. Manajemen Personalia Sumber Daya Manusia. Edisi Kedua, Yogyakarta: Penerbit BPFE.

Kreitner dan Kinicki. 2008. Organizational Behavior 10th Edition. South-Western: Thomson.

Luthans, Fred. 2006. Perilaku Organisasi. (Alih Bahasa V.A Yuwono, dkk), Edisi Bahasa Indonesia, Yogyakarta: ANDI.

Mangkunegara, Anwar Prabu. 2011. Evaluasi Kinerja SDM. Bandung: Remaja Rosda Karya.

Palan, R. 2007. Competency Management: Teknis Mengimplementasikan

Manajemen SDM Berbasis Kompetensi untuk Meningkatkan Daya Saing Organisasi. Jakarta: PPM.

Rivai, Veithzal. 2005. Evaluasi Kinerja. Bandung: Refika Utama. menggunakan variabel lain seperti budaya organisasi, gaya kepemimpinan, lingkungan kerja, dan lainnya. Sehingga diperoleh temuan yang lebih baik dalam menjelaskan kinerja pegawai.

Robbins, Stephen \& Timothy A. Judge. 2009. Perilaku Organisasi 1. Jakarta: Salemba Empat.

Robbins, Stephen. 2008. Perilaku Organisasi. Terjemahan: Benyamin Molan. New Jersey: Prentice Hall, Inc.

Sedarmayanti. 2007. Sumber Daya Manusia dan Produktivitas Kerja. Bandung: CV. Mandar Maju.

Sopiah. 2008. Perilaku Organisasi, Yogyakarta: Andi.

Sudarmanto. 2009. Kinerja dan Pengembangan Kompetensi SDM (Teori, Dimensi Pengukuran dan Implementasi dalam Organisasi). Yogyakarta: Pustaka Pelajar.

Suriasumantri, Jujun. 2003. Filasafat Ilmu: Sebuah Pengantar Populer. Jakarta. Sinar Harapan.

Wibowo. 2007. Manajemen Kinerja. Jakarta: PT. Rajagrafindo Persada. 